\title{
Erosion control reduces fine particles in runoff to Lake Tahoe
}

by Mark E. Grismer and A.L. Ellis

Sediment in hillslope runoff from disturbed soils in the Lake Tahoe Basin is the source of many fine suspended particles that transport nutrients and contribute to a loss in lake clarity. In previous studies, we used rainfall simulation to assess and quantify infiltration, runoff and erosion rates from hillslope soils. Building on this research, our current study evaluates the relationship between particle sizes in runoff sediments and slope, and compares the relationships between restored soil treatments and bare and undisturbed (native) forest soils. Soil restoration combined with pine needle mulch treatments substantially reduced sediment yields in runoff water, and increased the size of runoff particles when compared to that from bare soils. Very little, if any, runoff and erosion occurred from relatively undisturbed "native" soil plots at similar slopes.

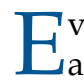
ver-increasing recreational use and housing development have increased the flow of sediments and nutrients into Lake Tahoe, decreasing its once-famous clarity by $30 \%$, from approximately 100 to 69 feet (30 to 21 meters), over the last 3 decades. This loss of clarity and a tripling of algal primary productivity (growth) indicate the onset of lake eutrophication (Goldman et al. 1989; TRG 2002). Swift et al. (see page 49) have demonstrated the importance of 1 to 8 micron $(\mu \mathrm{m})$ fine-sediment particles in diminishing the lake's clarity, both by transporting attached nutrients into the lake and scattering light when suspended in the water.

Road cuts and ski runs are important sources of damaging erosion and runoff in the Lake Tahoe Basin. Recently, regulators have increasingly focused on preventing runoff and retaining sediments

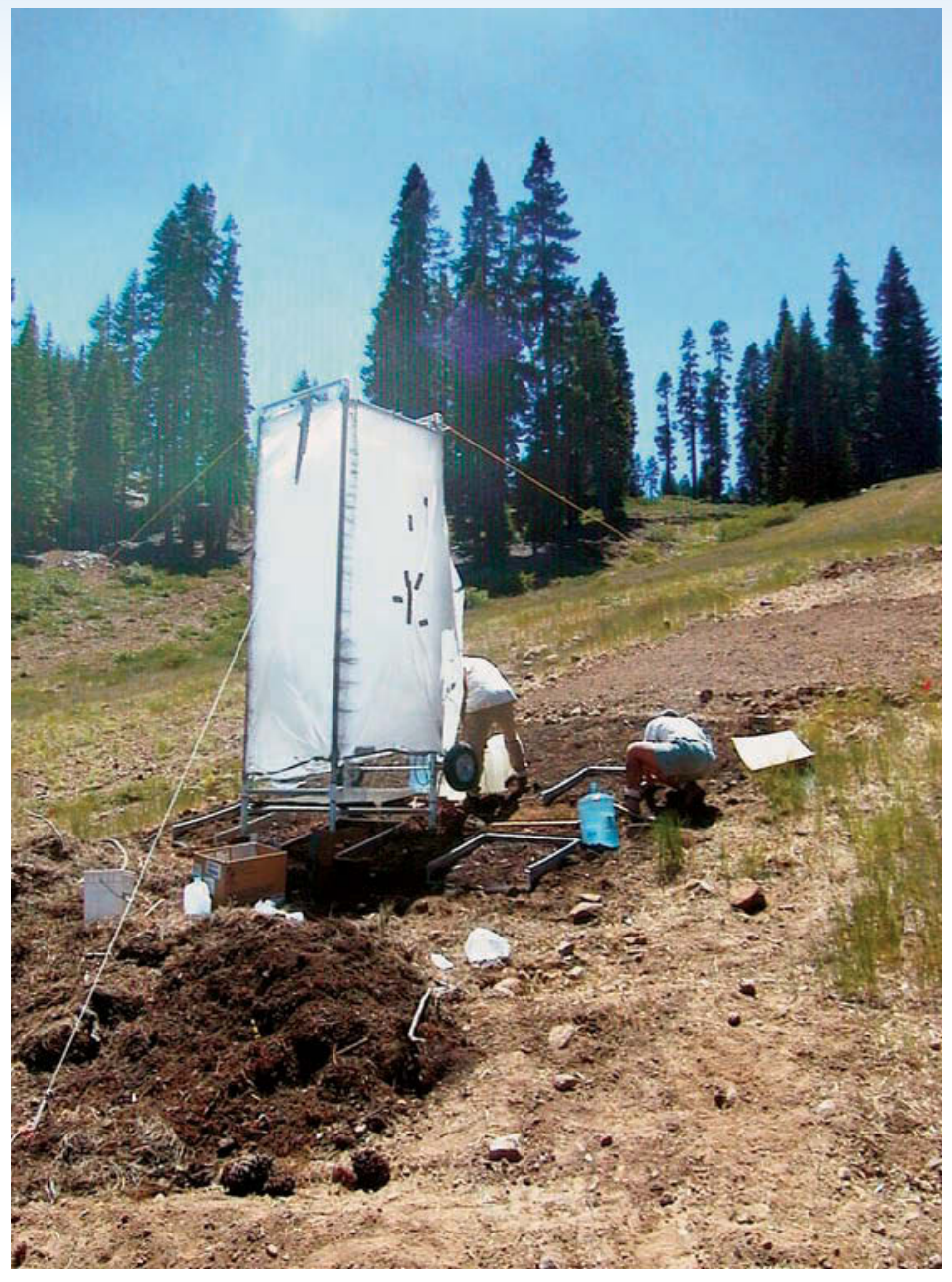

A rainfall simulator was used to measure sediments in runoff under a variety of soil and groundcover conditions in the Lake Tahoe Basin. within their original drainages (CTC 2001, 2004). The erosion-control treatments used at road cuts, ski runs and other sites in the basin can be broadly categorized, in order of decreasing runoff potential at a given slope, as: (1) bare soils (no treatment); (2) surface-treated soils, such as hydroseeded grasses, straw or mulch covers; (3) soil restoration treatments, such as tillage, the incorporation of woodchips, or compost combined with mulch covers; and (4) undisturbed "native" forest soils (Grismer and Hogan 2005b) (table 1). Unfortunately, several examples of erosion-control failures are visible in the semiarid, high-altitude environment of the Lake Tahoe Basin, especially along road cuts and ski runs.

Despite years of work, quantitative information has only recently been developed about the effectiveness of measures employed at road cuts and hillslopes to control erosion in the basin. In general, the literature related to erosion control involves agricultural activities and practices in relatively humid environments. There are few scientific field evaluations of erosioncontrol efforts involving revegetation and restoration in semiarid, subalpine environments such as the Lake Tahoe Basin. The information that is available on such environments is often limited to the "gray" literature of "white" papers from agencies or professional societies; these papers - while important - are not peer-reviewed or widely available, and so are not readily available for scientific scrutiny.

Nonetheless, erosion-control research and work are not new in the Tahoe Basin. For example, Maholland (2004) used geographic information system (GIS) assessment methods to determine that 


\section{Sediment yields were nearly} 10 times greater from volcanic ski-run soils and both types of road-cut soils than from undisturbed (native) sites.

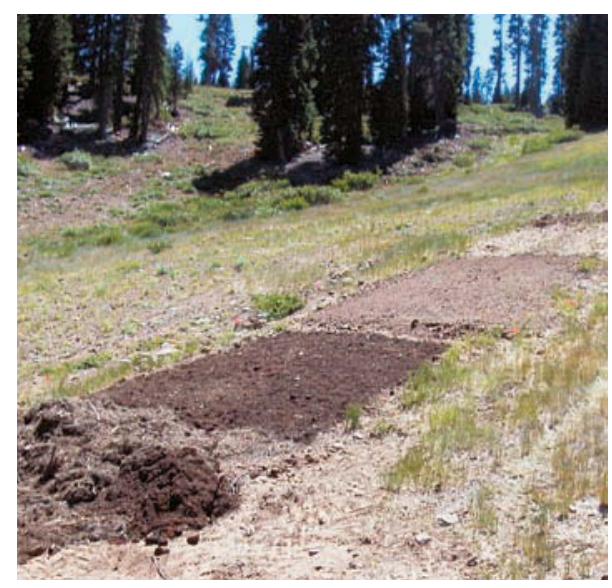

As expected, runoff from bare ground was greater than mulched and seeded plots, with a higher proportion of fine sediment particles.
TABLE 1. Estimated or known erosion-control treatment characteristics at Tahoe Basin rainfall simulation sites

\begin{tabular}{|c|c|c|c|c|c|c|}
\hline Site* & Seed mixt & Amends‡ & Fertilizer? & $\begin{array}{l}\text { Mulch } \\
\text { Type }\end{array}$ & Depth & $\begin{array}{l}\text { Tillage } \\
\text { depth }\end{array}$ \\
\hline & & & & & $\mathrm{mm}$ & $\mathrm{mm}$ \\
\hline \multicolumn{7}{|l|}{ Granitic soils } \\
\hline Bliss (RC) & None & Forest duff & None & Pine needle (PN) & 25 & 150 \\
\hline $\begin{array}{l}\text { Cave Rock (RC), } \\
\text { Heavenly Mt. (SR) }\end{array}$ & $\begin{array}{l}\mathrm{Br} \mathrm{ca}, \mathrm{El} \mathrm{el} \\
(100 \mathrm{~kg} / \mathrm{ha})\end{array}$ & Compost & Biosol & PN over straw & 50 & 150 \\
\hline Luther Pass - GV (RC) & El el, El gl, Br ca & Compost & Biosol & PN & 25 & None \\
\hline Rubicon (RC) & $\begin{array}{l}\text { Caltrans type-B } \\
\text { grasses - planted }\end{array}$ & Compost & $16-16-16$ & Straw and PN & $\sim 25$ & None \\
\hline \multicolumn{7}{|l|}{ Volcanic soils } \\
\hline Brockway (RC) & $\begin{array}{l}\text { Various grass mixes } \\
\text { (unknown) }\end{array}$ & Compost & Biosol & PN & 10 & 100 \\
\hline Dollar Hill — west (RC) & $\begin{array}{l}\text { Various bunchgrass } \\
\text { mixes }\end{array}$ & None & Biosol & PN, hand-applied & 30 & None \\
\hline Dollar Hill — east (RC) & $\begin{array}{l}\text { Native grasses over } \\
\text { std. mix w/yarrow }\end{array}$ & None & Biosol & Ground PN & 50 & None \\
\hline Northstar Unit 7 (RC) & El el, El gl, Br ca & $100 \mathrm{~mm}$ compost & Biosol & PN & 25 & 300 \\
\hline $\begin{array}{l}\text { Northstar (SRs) } \\
\text { (Lookout Mt.) }\end{array}$ & $\begin{array}{c}\text { Native and adapted } \\
\text { grasses }\end{array}$ & None & Biosol & Straw & 0 & \\
\hline $\begin{array}{l}\text { Snowking (SR) } \\
\text { (Juniper Mt.) }\end{array}$ & El el, El gl, Br ca & $\begin{array}{l}\text { Compost and } \\
\text { woodchips }\end{array}$ & Biosol & PN & 25 & 300 \\
\hline
\end{tabular}

* $\mathrm{SR}=$ ski run; $\mathrm{RC}=$ road cut.

$\dagger$ Various grass species: $\mathrm{Br}=\mathrm{Bromus}, \mathrm{El}=$ Elymus, $\mathrm{ca}=$ carinatus; $\mathrm{el}=$ elymoides; $\mathrm{gl}=$ glaucus .

Caltrans type-B grasses include fescues.

₹ Forest duff = broken-down organic litter matter on forest floor (fine powder).

I Biosol is a proprietary soil amendment; $16-16-16$ refers to the N-P-K content of the amendment. forest roads and ski runs subject to hillslope rilling (small channels created by concentrated runoff) were the greatest sources of sediment in the mixed granitic and volcanic soils of the Squaw Creek watershed, northwest of Lake Tahoe.

Furthermore, White and Franks (1978) documented the near total destruction of benthic (stream bottom) communities from the excessive discharge of sediments following development of the Rubicon Properties on Lake Tahoe's west shore. Their important demonstration study of various erosion-control nettings at the Rubicon housing development and Northstar-at-Tahoe ski area was "largely ignored in the erosion-control literature" (Sutherland 1998). As a white paper, White and Frank's study was not circulated widely and the results were not incorporated in other studies. Yet while it lacked scientific rigor, this was a model study with rarely seen cooperation between agencies in attempting to limit erosion in the Tahoe Basin. Other studies relevant to erosion in the Tahoe Basin include those conducted in the basin by Fifield et al. (1988) and in semi- arid, alpine western Colorado by Fifield et al. (1989), Fifield and Malnor (1990) and Fifield (1992a, 1992b).

\section{Standardized erosion evaluation}

Rainfall simulations are a useful method for standardizing the evaluation of erosion-control measures. These studies entail replicated rainfall events of the same intensity (or kinetic energy) on multiple plots, enabling the statistical evaluation of erosion-control treatments on hydrologic parameters. Grismer and Hogan (2004, 2005a, 2005b) employed rainfall simulation on disturbed road cuts and ski runs with granitic and volcanic soils in the Tahoe Basin to evaluate how slope, groundcover and surface roughness (microtopography) affect infiltration and runoff rates, as well as sediment concentrations and yields in runoff.

Soil survey information is limited for the Tahoe Basin, but all the soils can be broadly grouped into granitic, volcanic or a mix of the two, with surface soil textures of cobbly or stony sandy loams. Grismer and Hogan (2004, 2005a, 2005b) determined that surface roughness and cross-slope (the slope diagonal to straight downslope) had no effect on sediment concentrations or yields in runoff under all treatments encountered. In addition, for nearly all groundcover conditions, volcanic soils had greater runoff rates, sediment concentrations and yields than granitic soils (Grismer and Hogan 2004).

In these studies, runoff rates and sediment yields from bare soils were significantly correlated with slope. Sediment yields from bare granitic soils at slopes of $28 \%$ to $78 \%$ ranged from about 1 to 12 grams per millimeter per square meter $\left(\mathrm{g} / \mathrm{mm} / \mathrm{m}^{2}\right)$ runoff, while sediment yields from bare volcanic soils at slopes of $22 \%$ to $61 \%$ ranged from about 3 to $31 \mathrm{~g} / \mathrm{mm} / \mathrm{m}^{2}$ runoff (Grismer and Hogan 2005a). Furthermore, sediment yields were nearly 10 times greater from volcanic ski-run soils and both types of road-cut soils than from undisturbed (native) sites. Similarly, sediment yields were nearly four times greater from granitic ski-run soils than from native areas.

For both volcanic and granitic ski-run soils, revegetation or pine needle mulch 
decreased sediment concentrations and yields by $30 \%$ to $50 \%$. Regardless of rainfall intensity, there was little or no runoff or sediment yield from either soil type after the soil was restored by either incorporating woodchips or tilling amendments such as Biosol or compost into the soil, or applying mulch covers (with or without plant seeding).

\section{Sediment size in Lake Tahoe}

However, these previous studies did not analyze the particle-size distributions in runoff water, which is a critical component of Lake Tahoe's famed clarity and water quality. This paper reports on our study of the relationships between sediment concentration and yield, sediment yield and slope, and sediment particle size and slope for native (forest) and treated (at ski runs and road cuts) soils following rainfall simulation.

Battany and Grismer (2000) and Grismer and Hogan (2004) provide detailed descriptions of the rainfall simulation methodology that we used. The rainfall simulator consisted of a needle tank, tower assembly and associated plumbing hardware necessary to obtain steady rainfall intensity. Following a preliminary land survey of each site selected across the basin, several plots were established, the metal plot frame (31.5 inches by 31.5 inches [ 0.8 meter by 0.8 meter]) was installed, and the rainfall simulator was centered over the frame and leveled. Rainfall was allowed to continue until either steady runoff was obtained or about 60 minutes elapsed.

Following field measurements (including time to runoff, times of sample collection and surface topography), collected runoff samples were taken to the laboratory for filtration and analyses. Samples were vacuum-filtered first through a Whatman \#541 filter and then through a $0.45 \mu \mathrm{m}$ filter. Split samples were analyzed directly for particle-size distributions using the laser (Coulter) counting method (Eshel et al. 2004). The filter papers with sediment were dried at $105^{\circ} \mathrm{C}$ and then weighed, and total sediment mass per volume of runoff was determined. Sediment yield was determined as the slope of the linear

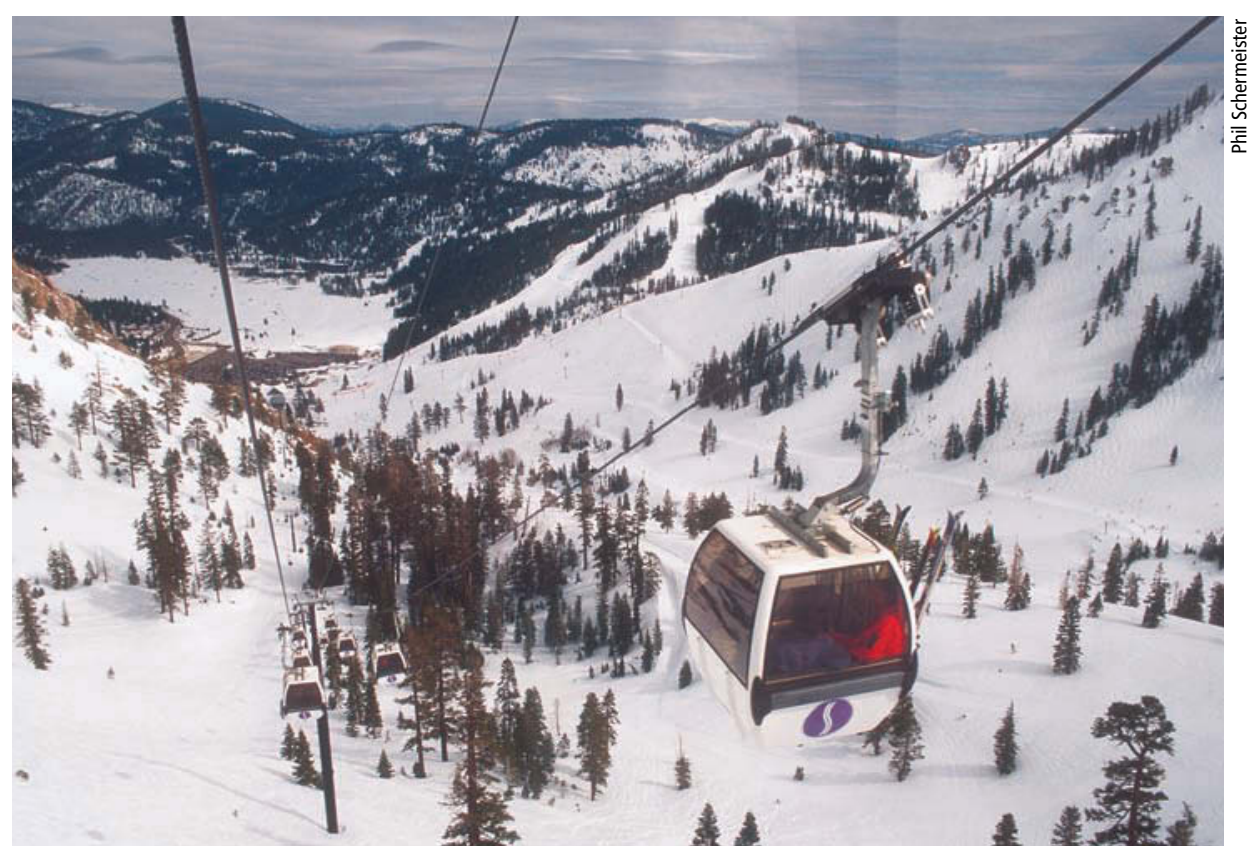

regression $\left(R^{2}\right.$ values ranged from 0.90 to 0.98 ) between cumulative sediment in the runoff and cumulative runoff. Steady sediment concentration in runoff was taken as the average of the last twoto-four individual sediment concentrations determined after runoff rates stabilized.

Several rainfall simulation tests were conducted during the summers of 2003 and 2004 on three soil types: volcanic, at Northstar (ski runs), Snowking (ski run) and Truckee highway interchanges (road cuts) on the north shore of Lake Tahoe; mixed, at a forest mastication test site near Tahoma on the west shore (see page 77); and granitic, at Heavenly Mountain Resort (ski run) and State Highway 89 (road cuts) on the south shore. At each site, rainfall simulation tests were conducted on three to six plots per treatment (bare, treated or native) and slope, depending on the relative consistency in measured val-

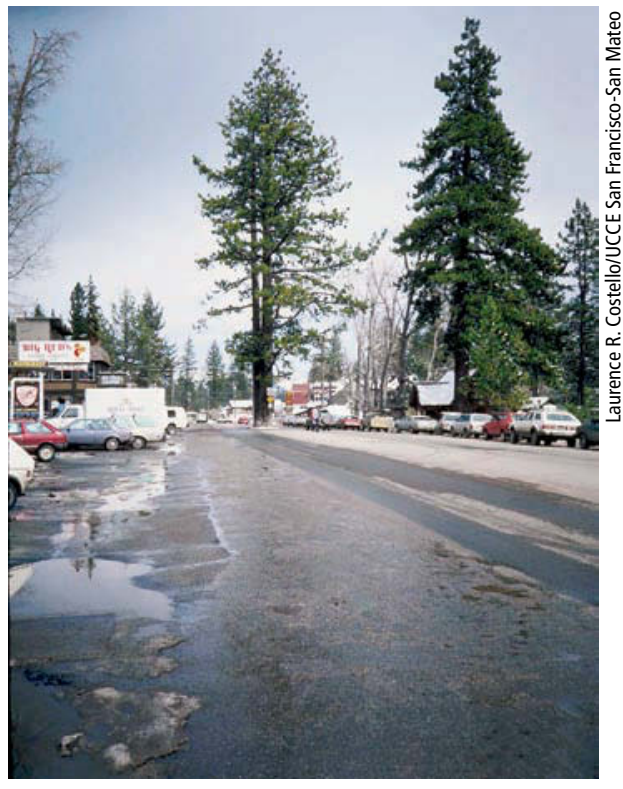

Runoff from, top, ski areas and urban roads such as in, above, Tahoe City, are important sources of sediments that are having an adverse impact on the storied clarity of Lake Tahoe.

TABLE 2. Laser particle-size distribution measurements (means and standard deviations) for Tahoe Basin disturbed soils

\begin{tabular}{lcccccccc}
\hline \hline Soil type & $\mathbf{n}$ & $\mathbf{D}_{\mathbf{1 0}}$ & \multicolumn{1}{c}{$\mathbf{D}_{\mathbf{3 0}}$} & \multicolumn{1}{c}{$\mathbf{D}_{\mathbf{6 0}}$} & $\mathbf{D}_{\mathbf{9 0}}$ & Sand & Silt & Clay \\
\hline Granitic mean & 16 & $70.4^{*}$ & $294.8 \mathrm{a}$ & $785.6 \mathrm{a}$ & $1,589 \mathrm{a}$ & $90.7 \mathrm{a}$ & $7.82 \mathrm{a}$ & $1.52 \mathrm{a}$ \\
Std. dev. & 16 & 30.2 & 91.9 & 146.4 & 83.5 & 3.19 & 2.90 & 0.55 \\
Volcanic mean & 48 & $3.98 \mathrm{~b}$ & $41.3 \mathrm{~b}$ & $390.1 \mathrm{~b}$ & $1,227 \mathrm{a}$ & $64.9 \mathrm{~b}$ & $28.2 \mathrm{~b}$ & $6.92 \mathrm{~b}$ \\
Std. dev. & 48 & 2.06 & 26.0 & 175.7 & 342.9 & 7.43 & 4.82 & 2.97 \\
Tahoma mean & 4 & $8.67 \mathrm{~b}$ & $66.0 \mathrm{~b}$ & $297.8 \mathrm{~b}$ & $1,194 \mathrm{a}$ & $74.0 \mathrm{c}$ & $21.8 \mathrm{c}$ & $4.20 \mathrm{ab}$ \\
Std. dev. & 4 & 3.06 & 6.39 & 54.2 & 245.6 & 2.11 & 1.45 & 0.85 \\
\hline * Mean values followed by different letters differ significantly $(P<0.05)$. & & & &
\end{tabular}


ues from plot to plot at similar slopes. Slope and soil type were taken as the independent variables, while sediment yield and particle-size fraction were the response variables as affected by plot treatment.

We characterized the particle-size distributions using the maximum size $\left(D_{x x}\right)$, with $x x$ corresponding to the percentage of particles less than that size. For example, the $\mathrm{D}_{50}$ particle size is the median, with $50 \%$ of the particles larger and $50 \%$ smaller; similarly, $10 \%$ of the soil particles are smaller than the $\mathrm{D}_{10}$ size. We considered particle sizes associated with less than $10 \%, 30 \%, 60 \%$ and $90 \%$ of the total sample $\left(D_{10}, D_{30}, D_{60}\right.$ and $D_{90}$, respectively). We then focused on the $D_{30}$ size, since it is often used to estimate soil infiltration rates and also roughly corresponds to the less-than-8$\mu \mathrm{m}$ particle size from the volcanic soils that are important to Lake Tahoe water clarity. Because we took measurements across a gradient (slope) and obvious differences resulted from soil type and treatment, we used regression analyses to develop possible causal relationships between slope and the response variables (sediment yield and particle-size fraction) (Cottingham et al. 2005).

\section{Reducing fine sediments}

Runoff and erosion rates from disturbed soils in the Tahoe Basin are primarily dependent first on soil type (granitic or volcanic), followed by the extent of soil restoration, and then slope and cover conditions (Grismer and Hogan 2004). While both soils are considered sand or sandy loam for any particular particle-size fraction, the average granitic particle sizes differed significantly (at 95\% level using Tukey standardized range test) from and were several times larger than those of the volcanic soils (table 2). The Tahoma soils at the mastication site are mixed volcanic and granitic, and this was reflected in the particlesize fractions that we found, which fell between those two soil types. Perhaps more importantly, there were more 1-to-8- $\mu \mathrm{m}$ particles in volcanic soils than granitic. Furthermore, Grismer and Hogan (2005a) found that soil

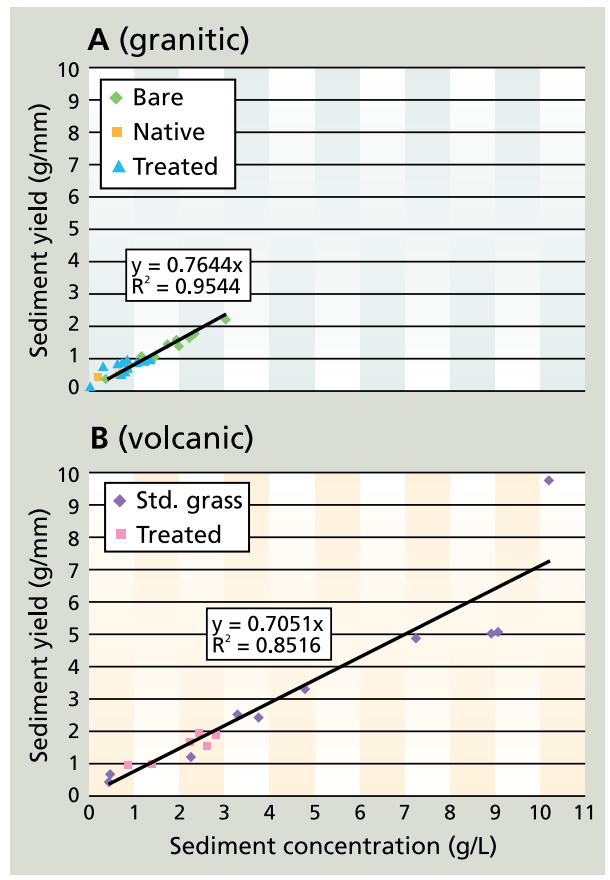

Fig. 1. Relationship between sediment yields and concentrations for all conditions from (A) granitic and (B) volcanic soils.

particle-size distributions tended toward the smaller sizes as slope increased in bare and treated disturbed soils.

To verify the consistency of using either sediment yield or sediment concentration to display our study results, we compared these two parameters for the two different soil types and all soil conditions (fig. 1). Not surprisingly, sediment yield was closely correlated with sediment concentration, particularly from bare soils (fig. 1A). However, the standard grass treatment was an annual grass (Fescue spp.) that provides $20 \%$ to $50 \%$ soil cover and does not include soil restoration (fig. 1B). In terms of runoff and erosion rates, this treatment was often similar to bare soils, although its ranges of cover caused

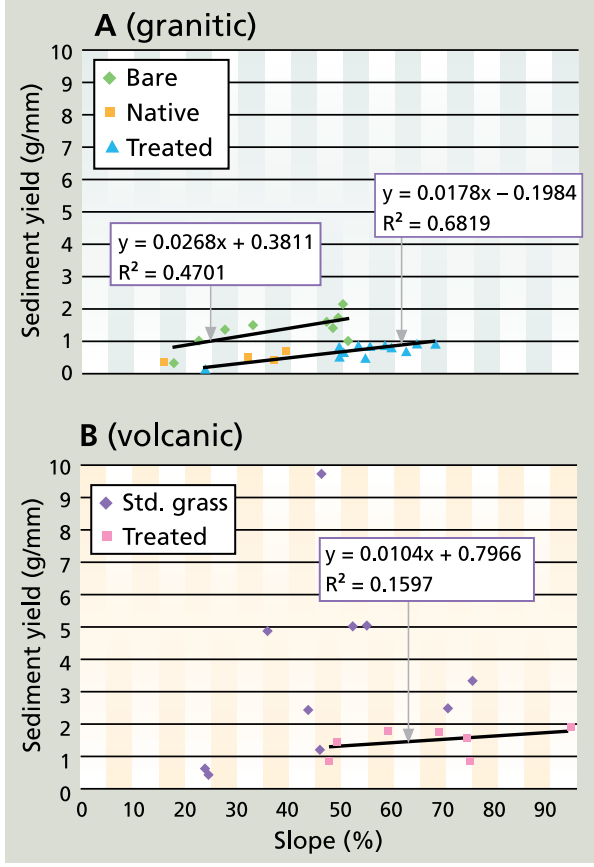

Fig. 2. Relationship between sediment yields and slope for all conditions from (A) granitic and (B) volcanic soils.

greater variability in the relationship between sediment yield and concentration; nonetheless, it appears that these two parameters can be used interchangeably (table 3).

Generally, runoff and erosion rates (sediment yields) increased with increasing plot slope, since gravity helps soil to detach and flow downward. We found this to be true for the granitic soils in our study, but much less so for the volcanic soils; in some cases no runoff occurred from native volcanic soil plots even as slope increased (fig. 2). Furthermore, the range of sediment yields from the volcanic soils was on average four times greater than that from the granitic soils. For example, at slopes of $50 \%$ to $55 \%$, sediment yields of about 5 grams per

TABLE 3. Statistics associated with regression relationships shown in figures 1, 2 and 3

\begin{tabular}{|c|c|c|c|c|c|c|}
\hline Soil type & Soil treatment & $\mathbf{n}$ & Relationship* & $\mathbf{R}^{2}$ & $\mathbf{F}$ & $P$ value \\
\hline Granitic & All & 25 & SY vs. SC & 0.954 & 477 & $<0.0001$ \\
\hline Volcanic & All & 16 & SY vs. SC & 0.852 & 80.595 & $<0.0001$ \\
\hline Granitic & Bare & 9 & SY vs. slope & 0.470 & 6.2075 & 0.04151 \\
\hline Granitic & Treated, native & 16 & SY vs. slope & 0.682 & 30.025 & $<0.0001$ \\
\hline Volcanic & Treated & 7 & SY vs. slope & 0.160 & 0.9524 & 0.37393 \\
\hline Granitic & Native & 4 & $D_{30}$ vs. slope & 0.979 & 93.238 & 0.01056 \\
\hline Granitic & Bare & 9 & $D_{30}$ vs. slope & 0.611 & 10.995 & 0.01284 \\
\hline Granitic & Treated & 12 & $D_{30}$ vs. slope & 0.321 & 4.7275 & 0.05477 \\
\hline Volcanic & Std. grass (Fescue sp.) & 7 & $D_{30}$ vs. slope & 0.312 & 2.2674 & 0.19246 \\
\hline Volcanic & Treated soil & 10 & $D_{30}$ vs. slope & 0.439 & 6.2603 & 0.03682 \\
\hline
\end{tabular}




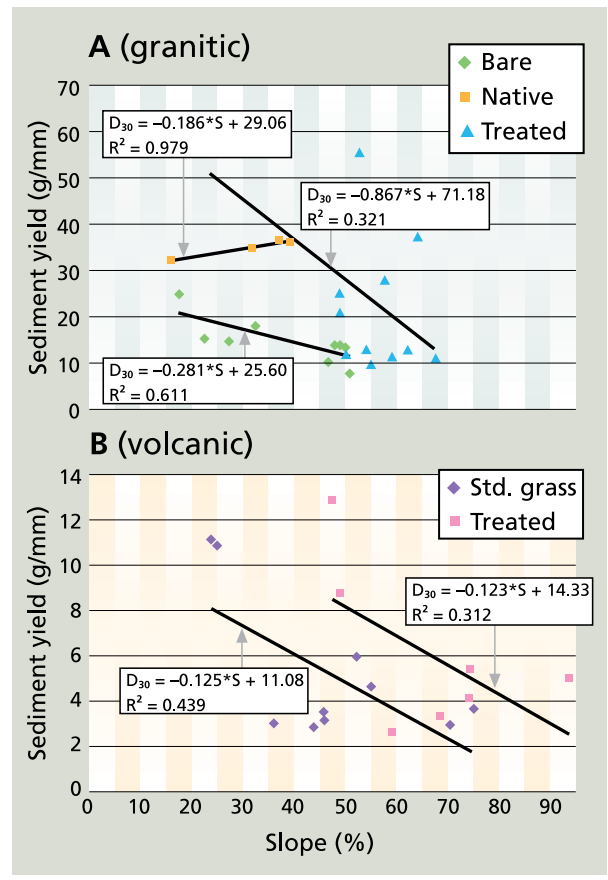

Fig. 3. Relationship between $D_{30}$ particle-size fraction and slope for all conditions from (A) granitic and (B) volcanic soils. Y-axis scales differ by a factor of five between granitic and volcanic soils.

millimeter occurred from the standard grass-covered volcanic soils, roughly three times greater than that from bare granitic soils and nearly seven times greater than that from treated or native granitic soils. Soil treatments - either mulch and grass covers only or more complete soil restoration - significantly decreased runoff rates and sediment yields as compared to bare soils. However, for many of these plots, the original treatment specifications and date of treatment were not well known, thus the longer-term efficacy of these different treatments and erosion-control approaches is not known and is currently under investigation.

While sediment yield, or total sediment deposition, is an important factor in evaluating the efficacy of various revegetation and soil restoration efforts, the smaller particle size of less than 8 $\mu \mathrm{m}$ is potentially more critical, because it contributes suspended particles - possibly with attached nutrients such as nitrogen and phosphorus - into receiving water bodies. As observed by Grismer and Hogan (2005b), in our study particle sizes also tended to decrease with increasing plot slope for bare and treated soils regardless of soil type (fig. 3). Four of the five regression relationships were significant at the 95\% level; however, given the limited results available for the native plots (where runoff rarely occurs), particle size in runoff did not appear to depend on plot slope. Clearly, this trend requires additional investigation; these studies are presently under way.

The $D_{30}$ particle sizes in runoff samples from volcanic soils were generally less than about $8 \mu \mathrm{m}$ for all conditions, while those from granitic soils generally exceeded about $10 \mu \mathrm{m}$ (fig. 3). As with the decreased sediment yields associated with soil treatment, larger particle sizes were observed from the treated or restored soils as compared to bare or standard grass-cover soils of both soil types.

\section{Effective erosion control}

The degree to which runoff particle size can be increased by an erosioncontrol treatment has important implications for developing best management practices (BMPs) for disturbed soils at road cuts, ski runs and construction sites in the Tahoe Basin. The development of effective erosion-control strategies is critical to preserving water clarity in Lake Tahoe, meeting total maximum daily load (TMDL) goals, and improving overall water quality. We found that volcanic soils have smaller particle sizes than granitic soils, and that they release particle sizes in the 1-to-8- $\mu \mathrm{m}$ range of concern with respect to Lake Tahoe's clarity. Revegetation, mulch covers and soil restoration tended to increase infiltration, decrease sediment yields and increase particle sizes in runoff across a range of slopes. We are currently trying to verify these results further, to help local agencies with limited resources to focus erosioncontrol work on, for example, volcanic soils that may yield the greatest reduction in fine-particle delivery to the lake.

M.E. Grismer is Professor, Departments of Land, Air and Water Resources, and Biological and Agricultural Engineering, and A.L. Ellis is M.S. Student, Department of Soils and Biogeochemistry, UC Davis. Caltrans supported this research.

\section{References}

Battany MC, Grismer ME. 2000. Development of a portable field rainfall simulator system for use in hillside vineyard runoff and erosion studies. Hydrologic Proc 14:1119-29.

Cottingham KL, Lennon JT, Brown BL. 2005. Knowing when to draw the line: Designing more informative ecological experiments. Frontiers Ecol Environ 3:145-52.

[CTC] California Tahoe Conservancy. 2001. Soil Erosion Control Grants Program, Program Announcement and Guidelines. July 2002. South Lake Tahoe, CA.

CTC. 2004. Formulating and Evaluating Alternatives for Water Quality Improvement Projects. Wallace E ( ed.). Lake Tahoe Basin Storm Water Quality Improvement Committee. South Lake Tahoe, CA.

Eshel G, Levy GJ, Mingelgrin U, Singer MJ. 2004. Critical evaluation of the use of laser light scattering for particle-size distribution analysis. Soil Sci Soc America J 68:736-43.

Fifield JS. 1992a. Comparative evaluation of erosion control products. Proc High Altitude Revegetation Workshop, Colorado St. Univ. CO Water Resources Res Inst Info Series No 71. p 133-48.

Fifield JS. 1992b. How effective are erosion control products in assisting with dry land grass establishment with no irrigation? Proc Intl Erosion Control Assoc Conf XXIII. p 321-33.

Fifield JS, Malnor LK. 1990. Erosion control materials vs. a semiarid environment - What has been learned from three years of testing? Proc Intl Erosion Control Assoc Conf XXI. p 233-48.

Fifield JS, Malnor LK, Dezman LE. 1989. Effectiveness of erosion control products on steep slopes to control sediment and to establish dry land grasses. Proc Intl Erosion Control Assoc Conf XX.

Fifield JS, Malnor LK, Richter B, Dezman LE. 1988. Field testing of erosion control products to control sediment and to establish dry land grass under arid conditions. Proc Intl Erosion Control Assoc Conf XIX.

Goldman CR, Jassby AP, Powell T. 1989. Interannual fluctuations in primary productivity: Meteorological forcing in two subalpine lakes. Limnol Oceanograph 34:310-23.

Grismer ME, Hogan MP. 2004. Evaluation of revegetation/mulch erosion control using simulated rainfall in the Lake Tahoe Basin: 1. Method assessment. Land Degradation Dev 13:573-88.

Grismer ME, Hogan MP. 2005a. Evaluation of revegetation/mulch erosion control using simulated rainfall in the Lake Tahoe Basin: 2. Bare soil assessment. Land Degradation Dev 16:397-404.

Grismer ME, Hogan MP. 2005b. Evaluation of revegetation/mulch erosion control using simulated rainfall in the Lake Tahoe Basin: 3. Treatment Assessment. Land Degradation Dev 16:489-501.

Maholland BL. 2004. Geomorphic assessment of natural and anthropomorphic sediment sources in an eastern Sierra Nevada watershed. MS in Hydrology, Univ Nevada, Reno.

Sutherland RA. 1998. Rolled erosion control systems for hillslope surface protection: A critical review, synthesis and analysis of available data. I. Background and formative years. Land Degradation Dev 9:465-86.

[TRG] Tahoe Research Group. 2002. Annual Lake Tahoe Report. UC Davis, Davis, CA.

White CA, Franks AL. 1978. Demonstration of erosion and sediment control technology: Lake Tahoe Region of CA. Municipal Environment Research Lab, Office of Research and Development. US EPA Demo Grant No S803181, Cincinnati, OH. 